\title{
Designing, Modelling And Analysis of The Edge Geometry ff Linear Lathe Tool Bit
}

\author{
Csaba Nemes1, Dr. Sándor Bodzás2, Dr. Sándor Pálinkás3 \\ ${ }^{1}$ University of Debrecen, Department of Mechanical Engineering, \\ H-4028, Debrecen, Ótemető str. 2-4. \\ e-mail: csabanemes94@gmail.com \\ ${ }^{2}$ University of Debrecen, Department of Mechanical Engineering, \\ H-4028, Debrecen, Ótemetö str. 2-4. \\ e-mail: bodzassandor@eng.unideb.hu \\ ${ }^{3}$ University of Debrecen, Department of Mechanical Engineering, \\ H-4028, Debrecen, Ótemetö str. 2-4. \\ e-mail: palinkassandor@eng.unideb.hu
}

\begin{abstract}
In this publication, with the help of our modelling software we have designed and modelled the edge geometry of the linear lathe tool in the model space. Our aim has been to develop a program which calculates the appropriate edge geometry with the help of some input length and angle dimensions. This is modelled in a wire frame model in a kind a file format that can be easily opened in the latest CAD softwares - so if some later modifications are needed, that can be done easily on the model. With the help of Finite Element Simulation [9, 10, 11] based on given loads, boundary conditions, technological parameters and material quality, an optimal edge geometry can be determined on the cutting tool for reaching the best cutting ratio.
\end{abstract}

Keywords: computer program, modelling, finite element method (FEM), simulation, optimization

\section{INTRODUCTION}

With the edge geometry of the cutting tools, the process of cutting can be influenced significantly $[2,7]$. From economical point of view, it is not indifferent to apply the most optimal edge geometry as possible, which results in good cutting conditions.

The different parameters should be taken into consideration in the process of optimization. We can intend for example to enhance the edge life of the tool or to enhance the material removal rate, or to have the material formation (chip formation) with the best type of chip which is appropriate for us (segmental, built up edge, continuous chips etc.). To improve the quality of the surface being cut can be also an aim, or to improve the parameters mentioned above all at the same time, however in these cases compromises will be necessary $[1,4]$.

To make a modelling program was important because in this way it is easy and fast to make cutting tools with different kinds of edge geometry in the model space. Modelling such a tool is time consuming and complex, more over it is easy to do it wrong because of the complexity of the task. Our program determines its model by mathematical way, so it must be exact. The usage and running of our program will be detailed later. It is important to mention that the program should not only have professional tasks but it should meet further requirements. These requirements consist of those criteria that a software today should be built in. For example, it should have graphic surface instead of earlier used character handling, it also should be expandable and upgradeable. It needs to be fast and its operation should be smooth, not burdened. The program also should have help functions in the menu etc.

\section{THE MODELLING PROGRAM}

Spatial lines are used to describe the geometry of the traditional turning tool. This means that certain simplifications are made on the tool to determine it. We neglect the fixing of the insert and arced surfaces. Thus, we do not take the fillet of the tool nose and the chip breaker keyway into consideration. On the tool, we do not draw the removable, hard metal insert either. Later you will see that in CAD program we are able to correct it.

\section{Theoretical background}

We chose the perpendicular, Descartes - type coordinate system (right handed orientation) so as to have the contact surface of the tool overlaps that of the plane of $\mathrm{X}-\mathrm{Y}$ and axis $\mathrm{Z}$ goes right through the nose of the tool.

After the simplification and application of the coordinate system, the following model is given. It is defined by spatial lines. The total number of 
spatial lines that make up the wire frame model is 26 (Figure 1).

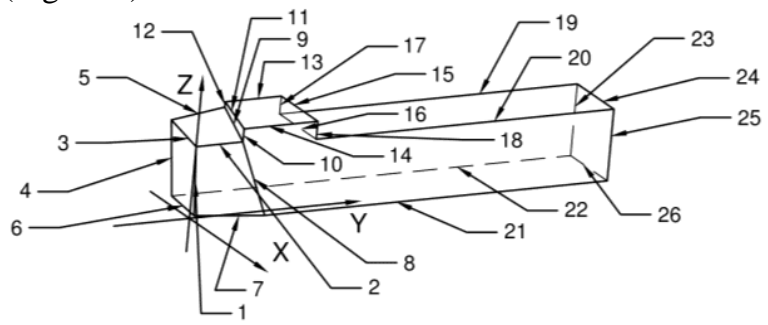

Figure 1 Wire frame model with the spatial lines

All of the spatial lines are intersecting each other; thus we get the so called corner points. The corner points of this model were named by the letters of $\mathrm{ABC}$ (Figure 2).

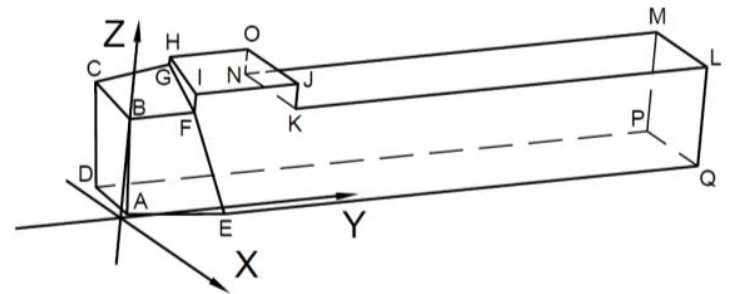

Figure 2 Wire frame model with corner points

These corner points are located in space as well, so to determine them $\mathrm{X}-\mathrm{Y}-\mathrm{Z}$ coordinates are required. As cutting tool geometry is defined by dimensions of angles and lengths [7, 8], so the equations of the spatial lines should be grouped in the model space, if we give the value of angles and lengths in the program, the position of the corner points should be calculated. After that the appropriate corner points should be linked to the lines and we got the wire frame model.

The following dimensions of lengths (Figure 3) and angles (Figure 4) should be given as input data to determine the wire frame model.

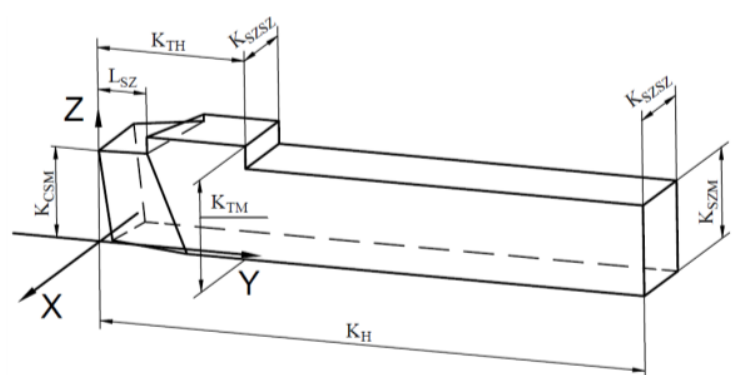

Figure 3 Length dimensions for determining the wire frame model

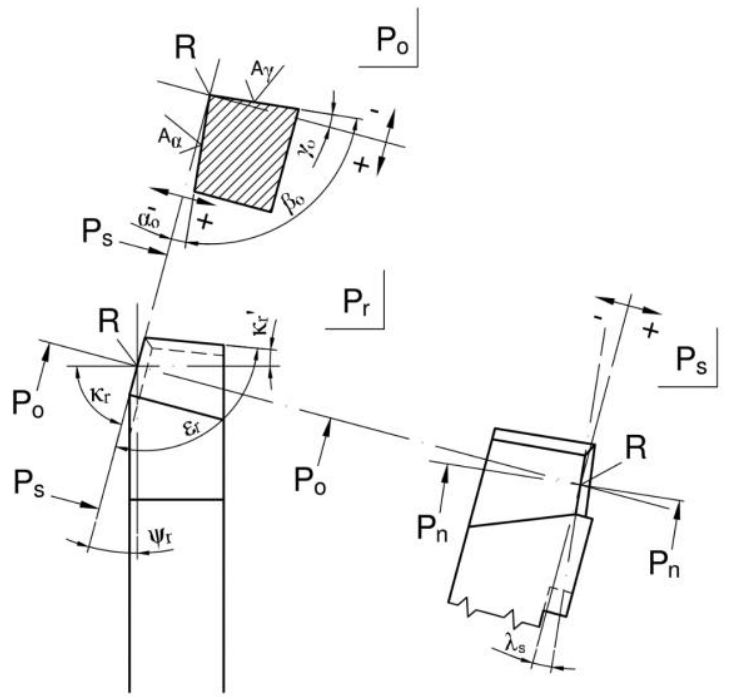

Figure 4 The necessary values of angle to determine the wire frame model

For simplifying reason, the orthogonal tool angle system was chosen to give the value of angles. We intended to define the cutting tool with the help of as less parameters as possible.

The total length of the tool should be given as input data $(125 \mathrm{~mm})$, more over the length of the tool body $(35 \mathrm{~mm})$, its height $(25 \mathrm{~mm})$, the height of the shank $(20 \mathrm{~mm})$, its width $(20 \mathrm{~mm})$, the width of the insert $(12 \mathrm{~mm})$, and the height of the tool nose $(20 \mathrm{~mm})$. In addition, Front cutting-edge angle $\left(75^{\circ}\right)$, Front clearance angle $\left(6^{\circ}\right)$, Side cutting-edge angle $\left(5^{\circ}\right)$, and its clearance angle $\left(6^{\circ}\right)$, and also the angle of guide $(\sim)$, and the rake angle $(\sim)$ should also be given. Given all these data above, the software can draw the wire frame model. In brackets the parameters of our tool used in this simulation are shown.

\section{Definition of spatial lines in the appropriate form}

As you can see, during the calculation of the coordinates of the following points, there is uniformity. So it is enough to define the given coordinate of one point and then you can get the related coordinates of the other points.

Uniformities are the following:

$C_{x}=D_{x}=G_{x}=H_{x}=M_{x}=N_{x}=O_{x}=P_{x}$

$E_{x}=F_{x}=I_{x}=J_{x}=K_{x}=L_{x}=Q_{x}$

$G_{y}=H_{y}$

$F_{y}=I_{y}$

$J_{y}=K_{y}=N_{y}=O_{y}$

$L_{y}=M_{y}=P_{y}=Q_{y}$

$L_{y}=M_{y}=P_{y}=Q_{y}$

$A_{z}=D_{z}=E_{z}=P_{z}=Q_{z}$

$H_{z}=I_{z}=J_{z}=O_{z}$ 
$K_{z}=L_{z}=M_{z}=N_{z}$

There is no need of calculating the coordinates of some corner points, because those values are fix (zero), or they are the same as the given data in our program. The coordinates of the corner points are the following:

$$
\begin{aligned}
& A\left(\boldsymbol{A}_{\boldsymbol{x}} ; \boldsymbol{A}_{\boldsymbol{y}} ; 0\right) \\
& B\left(0 ; 0 ; K_{C S M}\right) \\
& C\left(\boldsymbol{C}_{\boldsymbol{x}} ; \boldsymbol{C}_{\boldsymbol{y}} ; \boldsymbol{C}_{\boldsymbol{z}}\right) \\
& D\left(D_{x} ; \boldsymbol{D}_{\boldsymbol{y}} ; 0\right) \\
& E\left(E_{x} ; \boldsymbol{E}_{\boldsymbol{y}} ; 0\right) \\
& F\left(\boldsymbol{F}_{\boldsymbol{x}} ; \boldsymbol{F}_{\boldsymbol{y}} ; \boldsymbol{F}_{\boldsymbol{z}}\right) \\
& G\left(G_{x} ; \boldsymbol{G}_{\boldsymbol{y}} ; \boldsymbol{G}_{\boldsymbol{z}}\right) \\
& H\left(H_{x} ; H_{y} ; K_{T M}\right) \\
& I\left(I_{x} ; I_{y} ; K_{T M}\right) \\
& J\left(J_{x} ; K_{T H} ; K_{T M}\right) \\
& K\left(K_{x} ; K_{T H} ; K_{S Z M}\right) \\
& L\left(L_{x} ; K_{H} ; K_{S Z M}\right) \\
& M\left(M_{x} ; K_{H} ; K_{S Z M}\right) \\
& N\left(N_{x} ; K_{T H} ; K_{S Z M}\right) \\
& O\left(O_{x} ; K_{T H} ; K_{T M}\right) \\
& P\left(P_{x} ; K_{H} ; 0\right) \\
& Q\left(Q_{x} ; K_{H} ; 0\right)
\end{aligned}
$$

Coordinates written in bold are unknown for us. After having the equations, those are programmed in C\# program language. The coordinates which are not in bold, due to the above-mentioned uniformity are given, or they have fix values or they should be necessarily given in the program (like certain angles and lengths dimensions).

\section{The usage of the modelling program}

This program is capable of running without the development surrounding, independently. It has got graphical surface, which after opening the program looks like the following (Figure 5).

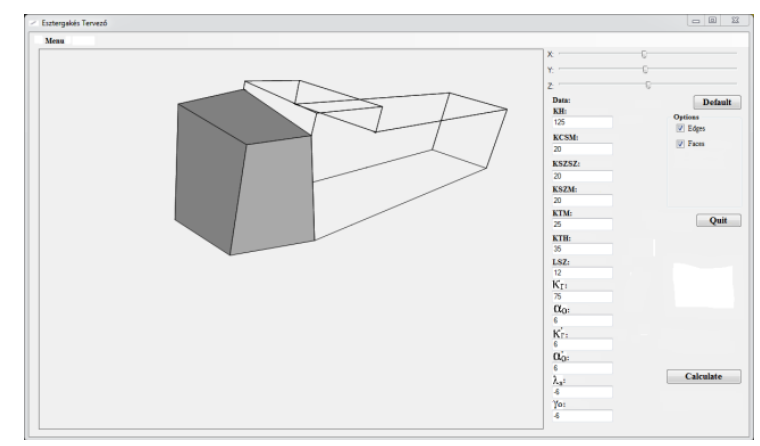

Figure 5 The modelling software after opening

The program can be divided into 2 parts. Its right side is the user interface, where the necessary dimensions should be given. The saving of the model also happens here and you can close the program from here as well. Its left side is a screen where the generated wire frame model is shown based on the given input data. The model can be rotated with the help of the X-Y-Z slides found on the right side, because these lead the rotation around a given axis.

In the Options submenu, there is a possibility to see the edges and the surfaces so you can have a model bounded by surfaces. With the help of the 'Default' button you can restore the original state after opening. By clicking on 'Calculate' button a usual screen appears and you can actually save the calculated data in a given file format.

\section{WIRE FRAME MODEL IN CAD SOFTWARE}

The wire frame model generated by our modelling software can be opened by CAD program. Thus, further modifications can be made here if necessary.

\section{The imported model}

You can see the imported model below (Figure 6).

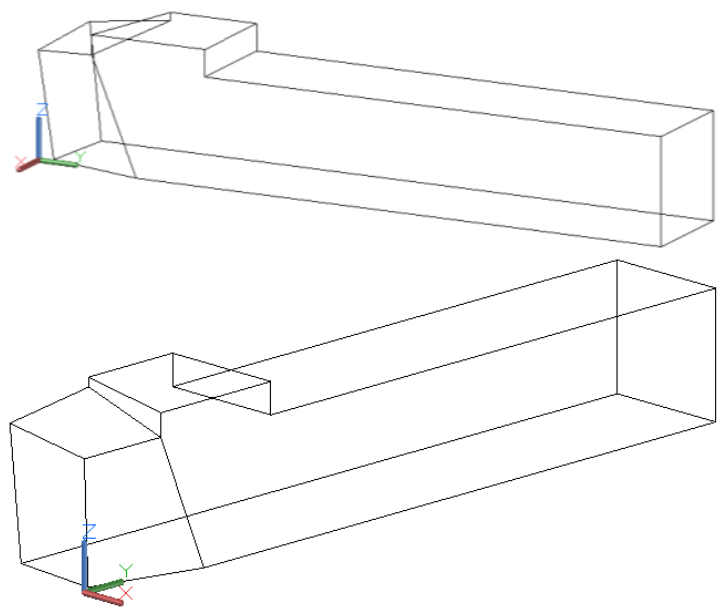

Figure 6 The imported wire frame model

As a matter of fact, certain sections of those spatial lines, which were determined before or programmed, appear on the screen. After importing, the lathe tool is covered with surfaces. With this action, you can have a boundary between the inner space of the tool and the surrounding. You can see our model after covering below (Figure 7). 


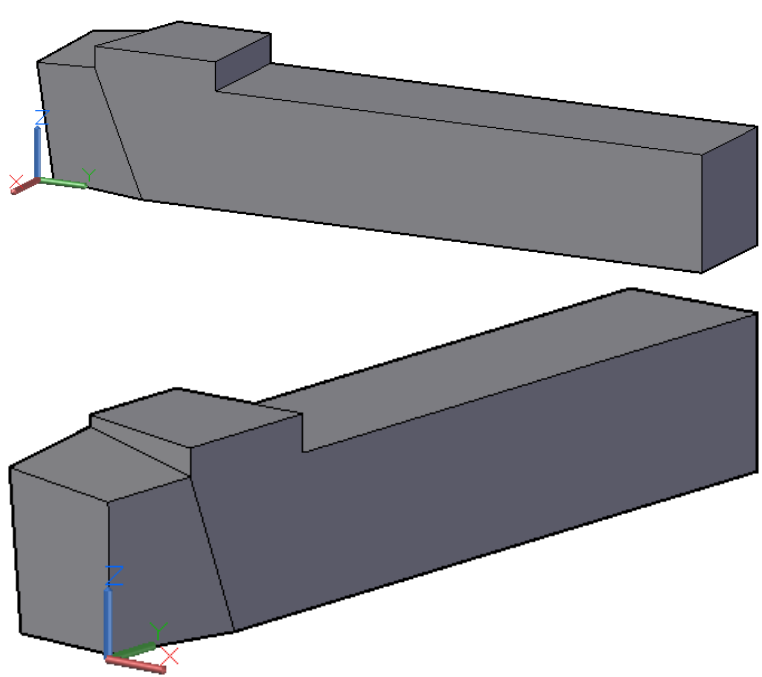

Figure 7 Our model bounded by surfaces

The CAD software program automatically covers the tool after importing, because the program creates these surfaces together with the wire frame model so creating the model will be faster. After that, depending on the CAD software by using the 'convert' command we transform the model into a solid body (Figure 8).

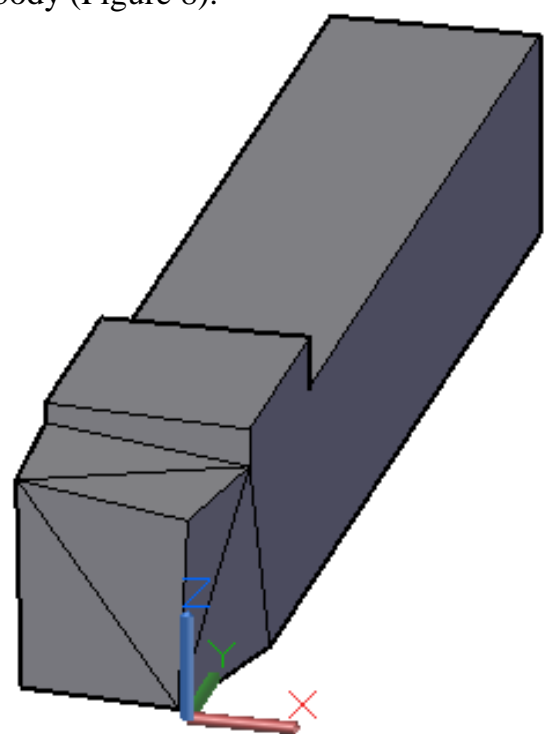

Figure 8 Solid body model

The major difference between the model bounded by surfaces and the solid body model is that the later one is handled as a solid, 'concise material'. Because of this, the conversion must be done and this gives you the possibility to modify the model if necessary. Sections can be made, parts of material can be added and reduced.

\section{The modified model}

The earlier ignored arc surfaces can have the possibility to be taken into consideration again now. Due to the CAD software, the model can be further modified, thus we can create the arced surfaces on the model. First the creation of the fillet of the nose radius is shown. The fillet has $1 \mathrm{~mm}$ radius (Figure 9).

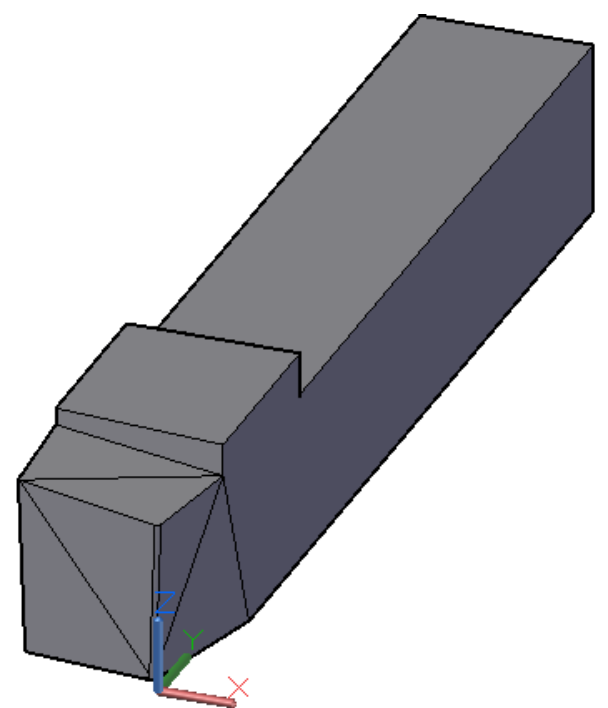

Figure 9 Creating the fillet of the nose radius

Beside the fillet of the nose radius it is important to have the chip breaker keyway. You can see the keyway on the next figure below (Figure 10). The depth of the keyway is $0.5 \mathrm{~mm}$ and its radius is $1 \mathrm{~mm}$. Moreover it has $1 \mathrm{~mm}$ distance from the edges, which is called as edge strip.

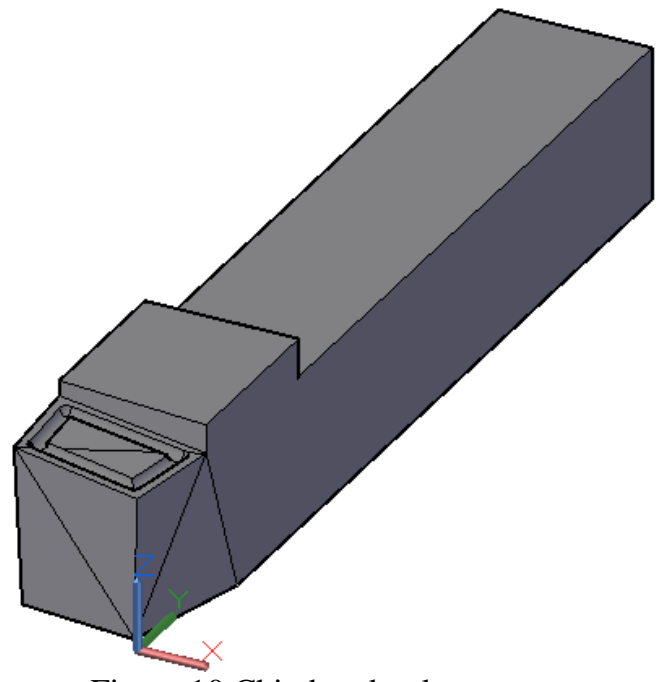

Figure 10 Chip breaker keyway

After the smoothing command, our model can be seen below together with the chip breaker keyway and the nose radius fillet (Figure 11). 


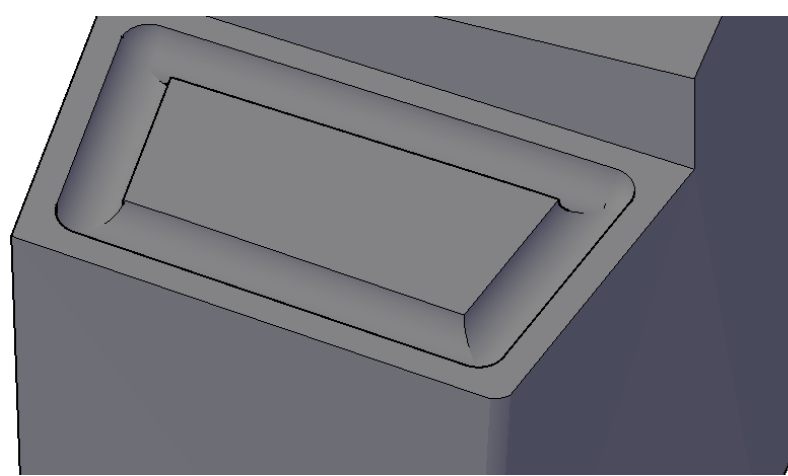

Figure 11 After smoothing the nose radius fillet and the chip breaker keyway

\section{CUTTING SIMULATION WITH FINITE ELEMENT METHOD (FEM)}

During the simulations one material quality was applied for the workpiece and one for the tool insert but three different kinds of edge geometry were used. In all simulations, the same finite element- and technological parameters were used. In the further sections, you will see that the structure of the model in practice is more likely to resemble of the technology of planing.

For the finite element simulations Ansys 18.1 program Academic version was used.

\section{Creating the model}

During simulation, the whole tool body is not important, thus only some parts of the edge geometry (the working part) remained, and we did not take the other parts into consideration. This working part can be seen as a removable, HM insert in practice (Figure 12). Moreover, we ignore the arced surfaces as well because we are only interested in those effects which happen as a function of the change of the angle of guide and the rake angle. Our model was built so that only the front cutting edge does the process of cutting, the side cutting edge and the nose of the tool do not $[3,5,8]$.

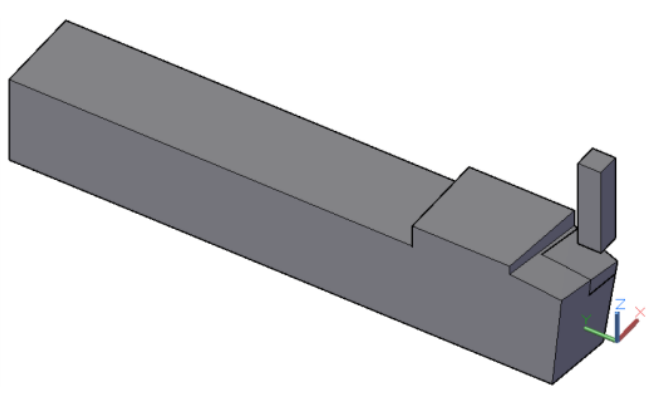

Figure 12 The tool body and the workpiece

The workpiece can be seen relatively small compared to the cutting tool, however this is enough to deduce the cutting ratios. The model used in the simulation can be seen below:

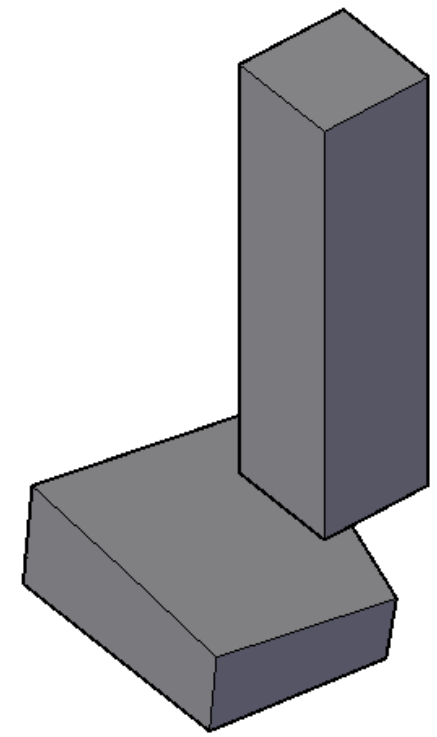

Figure 13

The working part and the workpiece

From this section on only the inserts are changed into different geometry and you can again run the simulation. This is the point why it is worth having this modelling program because a different tool geometry can be structured within a second. This new tool is then changed by the later one and the simulation can be run again [10].

\section{Defining the Laws of Materials}

In the finite element simulation, the Johnson Cook [6] material model was chosen. In the model, the yield point is depending on the plastic deformation, the speed of deformation, and the temperature. The correlation between the members can be seen in the equation below.

$$
\sigma=\left(A+B \cdot \varepsilon_{p}^{n}\right)\left[1+C \cdot \ln \left(\frac{\dot{\varepsilon}}{\dot{\varepsilon}_{0}}\right)\right]\left[1-\left(\frac{T-T_{r}}{T_{m}-T_{r}}\right)^{m}\right]
$$

In addition to, the equation published by Johnson- Cook was also applied for the description of deterioration of the material. The equation is the following:

$\varepsilon^{f}=\left[D_{1}+D_{2} e^{D_{3} \sigma^{*}}\right]\left[1+D_{4} \ln \left(\frac{\dot{\varepsilon}}{\dot{\varepsilon_{0}}}\right)\right][1+$

$\left.D_{5}\left(\frac{T-T_{r}}{T_{m}-T_{r}}\right)\right]$

The applied kinds of material quality and deterioration values can be found in the following table. In case of the tool we did not define deterioration value. 
Table 1 Deterioration values [6]

\begin{tabular}{|c|c|}
\hline $\mathbf{A}[\mathbf{M P a}]$ & OFHC Copper \\
\hline $\mathbf{B}[\mathbf{M P a}]$ & 90 \\
\hline $\mathbf{n}[-]$ & 292 \\
\hline $\mathbf{C}[-]$ & 0.31 \\
\hline $\mathbf{m}[-]$ & 0.025 \\
\hline $\mathbf{D}_{\mathbf{1}}[-]$ & 1.09 \\
\hline $\mathbf{D}_{\mathbf{2}}[-]$ & 0.54 \\
\hline $\mathbf{D}_{\mathbf{3}}[-]$ & 4.89 \\
\hline $\mathbf{D}_{\mathbf{4}}[-]$ & -3.03 \\
\hline $\mathbf{D}_{\mathbf{5}}[-]$ & 0.014 \\
\hline
\end{tabular}

Table 2: Material quality of the tool [12]

\begin{tabular}{|c|c|}
\hline Density, $\boldsymbol{\rho},\left[\frac{\mathrm{kg}}{\mathrm{m}^{\mathbf{3}}}\right]$ & Carbide tool \\
\hline $\begin{array}{c}\text { Elastic modulus, E, } \\
{[\mathbf{G P a}]}\end{array}$ & 15700 \\
\hline Poisson's - ratio, $\mathbf{v},[-]$ & 705 \\
\hline Conductivity, $\mathbf{k},\left[\frac{\boldsymbol{W}}{\mathrm{m} \cdot \mathbf{K}}\right]$ & 0.23 \\
\hline Specific heat, $\mathbf{c}_{\mathbf{p}},\left[\frac{\mathrm{J}}{\mathrm{kg} \cdot \boldsymbol{K}}\right]$ & 24 \\
\hline
\end{tabular}

Table 3 Material quality of the workpiece [6]

\begin{tabular}{|c|c|}
\hline & OFHC Copper \\
\hline $\begin{array}{c}\text { Elastic modulus, } \mathbf{E}, \\
{[\mathrm{GPa}]}\end{array}$ & 124 \\
\hline Poisson's - ratio, v, [-] & 0.34 \\
\hline $\begin{array}{c}\text { Shear modulus, } \mathbf{G}, \\
{[G P a]}\end{array}$ & 46 \\
\hline $\begin{array}{c}\text { Bulk modulus, } \mathrm{B}, \\
{[\mathrm{GPa}]}\end{array}$ & 129 \\
\hline Density, $\rho,\left[\frac{\mathrm{kg}}{\mathrm{m}^{3}}\right]$ & 8960 \\
\hline Conductivity, $\mathrm{k},\left[\frac{W}{m \cdot k}\right]$ & 386 \\
\hline Specific heat, $c_{p},\left[\frac{J}{k g \cdot K}\right]$ & 383 \\
\hline $\begin{array}{l}\text { Melting temperature, } \\
\qquad T_{m},[K]\end{array}$ & 1356 \\
\hline
\end{tabular}

FEM meshing and movements

In each and every simulation the tool insert was chosen to be $1.2 \mathrm{~mm}$ element big, while the workpiece was $0.6 \mathrm{~mm}$ element big. More dense meshing did not result in any significant difference (more precise) so we can state that the set values are correct.

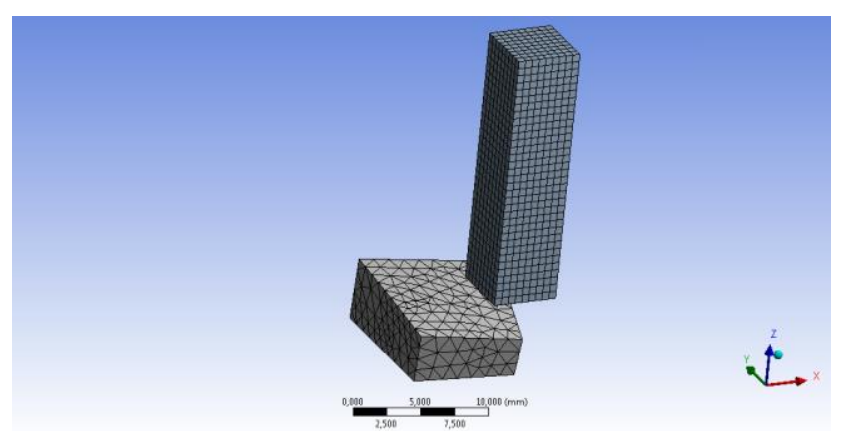

Figure 14

Meshing

The movement of the workpiece is along axis $\mathrm{Z}$ in negative way, as you can see on Figure 15.

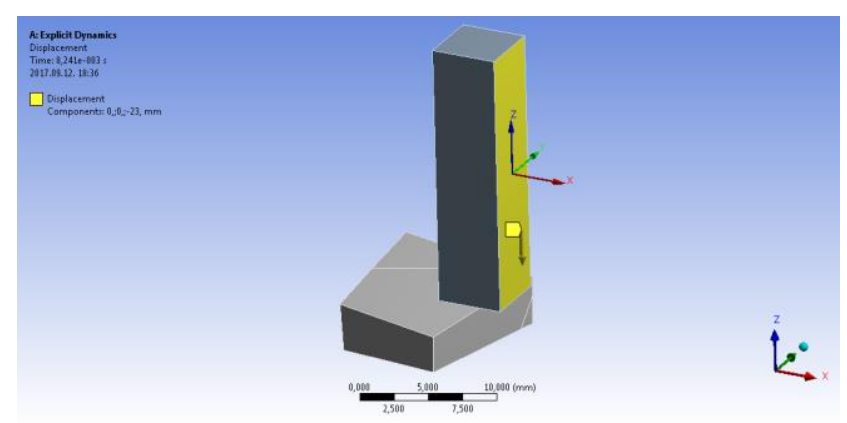

Figure 15

The movement of the workpiece

To analyse the tool inserts, a relatively high cutting speed was chosen. This was because the technology of cutting nowadays intends to have higher and higher cutting speed. This is due to the fact that in this way, in some cases coolant is not necessary to have (environmentally friendly) and the material removal rate is also higher (economical).

The chosen cutting speed is: $168\left[\frac{\mathrm{m}}{\mathrm{min}}\right]$. The displacement was set to $23 \mathrm{~mm}$ after considering the dimensions of the workpiece $(5 \times 5 \times 20 \mathrm{~mm})$ and the approach and over travel distances.

\section{The Results of the Simulation}

All the results are within the $10 \%$ error limit. The slip - friction factor is in all the simulations: $\mu=$ 0.2 . In finite element simulation, the cutting process happens in three steps. First the 'negative' tool insert, then the 'zero' and finally the 'positive' insert was applied. When 'negative' is mentioned, it means $-6^{\circ}$ angle of guide, and $-6^{\circ}$ rake angle. 'Zero' means both of the angles are $0^{\circ}$, and if 'positive' is mentioned, it means both of the angles are $6^{\circ}$.

All three inserts that are simulated have OFHC Copper material quality. The analyses of the results were divided into 2 sections. First the temperature values were compared, then equivalent stress values 
were also compared (Figure 16, Figure 17). In the former case, tool insert is not shown individually because after such a little of cutting process, insignificant amount of heat was created $\left(30^{\circ} \mathrm{C}\right.$ $\left.70^{\circ}\right)$.

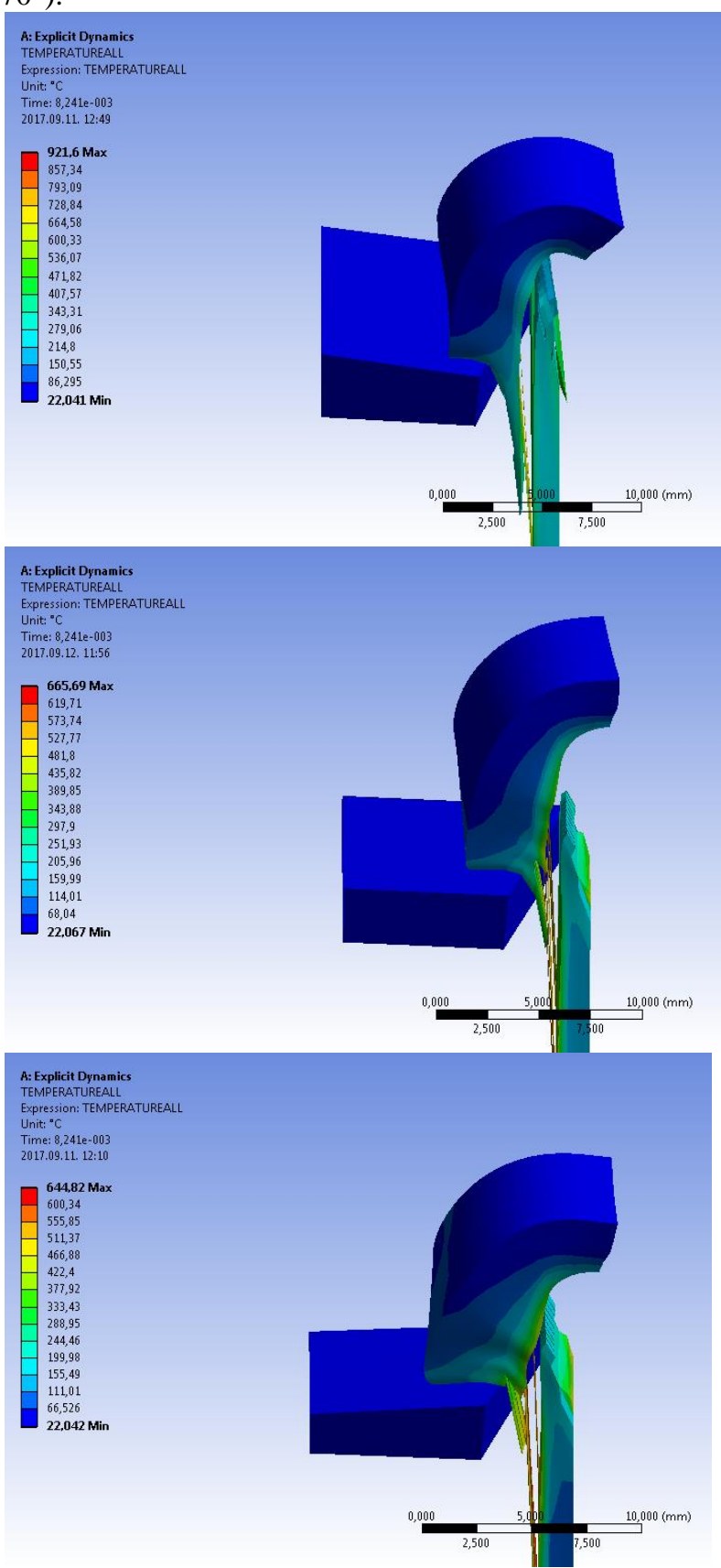

Figure 16

Temperature values in case of OFHC Copper
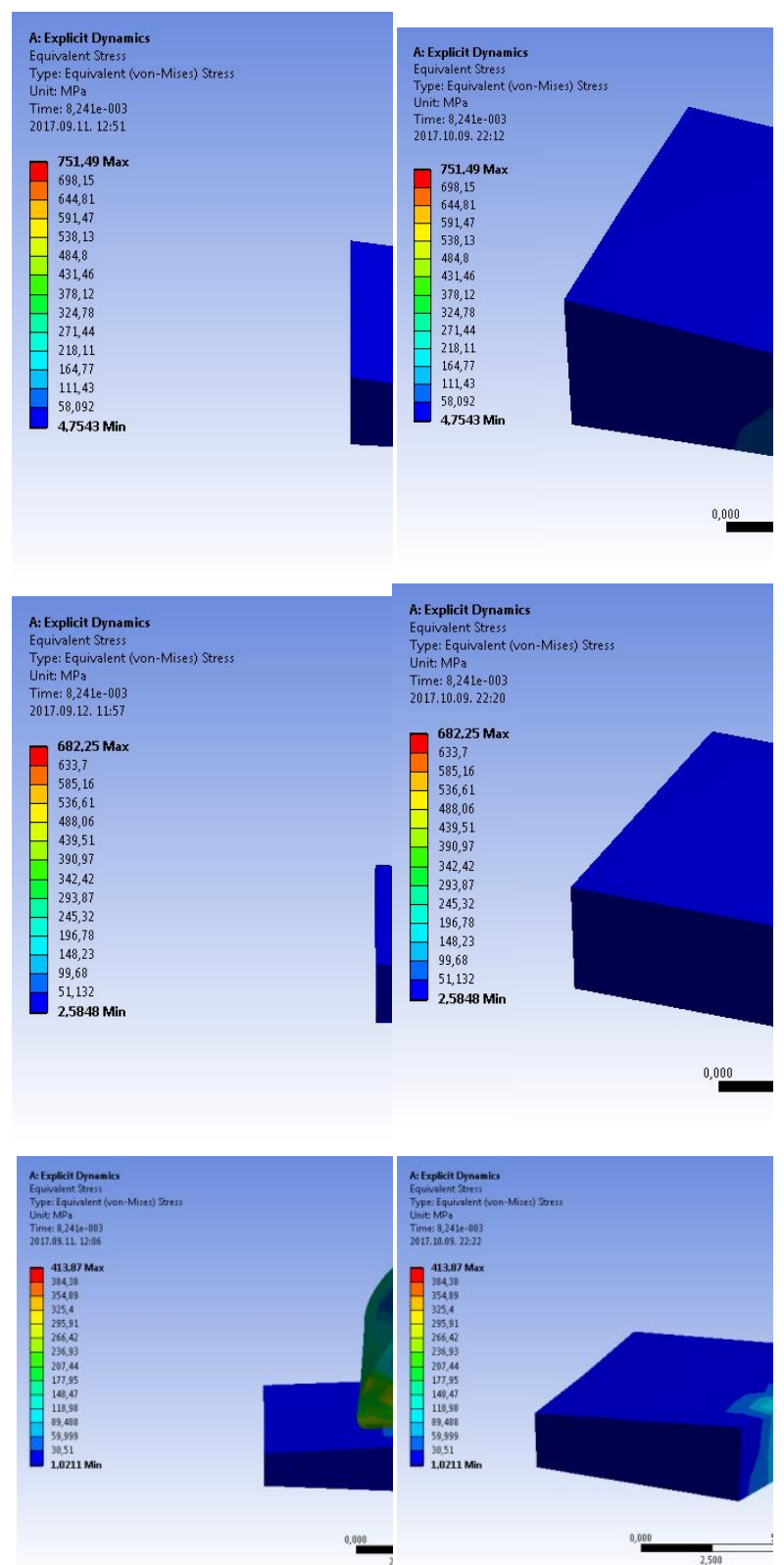

Figure 17

Equivalent stress values in case of OFHC Copper

In case of OFHC Copper material quality we can state that using 'negative' insert causes a very significant temperature rise. In cases of 'zero' and 'positive' inserts, this temperature value reduces remarkably. Thus, for this kind of material quality it is clear that later two kinds of inserts insure much better temperature rise parameters. However, the equivalent stress figures show that from 'zero' and 'positive' inserts, the later one is more appropriate because it evokes much less stress values which refers to better cutting ratios. These values can be further reduced with the use of a chip breaker keyway. 


\section{CONCLUSION}

The edge geometry of the cutting tool could be now mathematically calculated. The equations of the spatial lines have been determined, then they have been structured in the appropriate form.

The equations have been programmed in $\mathrm{C \#}$ program language. A modelling software has been created which can operate without the developing platform.

Models drawn by our modelling software can be opened in CAD and Finite Element Programs. Due to this fact the model can be used for further analysis and examinations.

Finite Element Analyses have been made and we drew the conclusions from the results. For optimizing the cutting parameters, we have made recommendations.

From our results, it can be seen that the insert having 'positive' rake angle and angle of guide caused lower temperature rise and less stress which suggests better cutting parameters.

The project was implemented by the Ministry of Human Resources through the New National Excellence Program of the Higher Education Master's Degree Researcher's Scholarship. Project number: ÚNKP-18-2-I-DE-100.
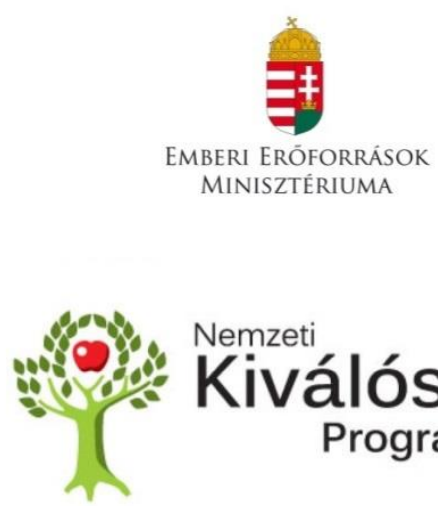

Nemzeti

Kiválóság Program

The work/publication is partly supported by the EFOP-3.6.1-16-2016-00022 project. The project is co-financed by the European Union and the European Social Fund.

\section{REFERENCES}

[1] BAKONDI K., KARDOS Á.: A gépgyártás technológiája, I. Forgácsolás, Második kiadás, Tankönyvkiadó, Budapest, 1966., p. 382.
[2] BÁLINT L.: A forgácsoló megmunkálás tervezése, Müszaki Kiadó, Budapest, 1958.

[3] DUCSAI J.: Forgácsolási eljárások, Tankönyvmester Kiadó, Budapest, 2013., ISBN 978-963-275-082-8

[4] FRIDRIK L.: Forgácsolás I., (Forgácsoláselmélet), Miskolci Egyetemi Kiadó, 2011, p. 206.

[5] GYÁNI K.: Gépgyártástechnológia alapjai I., Tankönyvkiadó, Budapest, 1979, p. 131.

[6] JOHNSON G. R., COOK W. H.: A constitutive model and data for metals subjected to large strains, high strain rates and high temperatures, Proceedings 7th International Symposium on Ballistics, The Hague, 19-21 April 1983, p. 541-547.

[7] KOZMA F.: Forgácsoláselmélet, Kossuth Lajos Tudományegyetem, Müszaki Föiskolai Kara, Debrecen, 1995.

[8] KOZMA F.: Forgácsolás technológiája I. (Esztergálás, Gyalulás, Vésés és Üregelés), Kossuth Lajos Tudományegyetem, Müszaki Föiskolai Kara, Debrecen, 1996.

[9] MANKOVITS T., HURI D.: Modellezés és szimuláció (A lineáris rugalmasságtan és a végeselem-módszer), Debreceni Egyetem, 2015.

[10] NEMES CS., BODZÁS S.: Egyenes esztergakés tervezése, modellezése és vizsgálata, Müszaki Tudomány az Észak Kelet Magyarországi Régióban 2017, Konferencia Elöadásai, Nyíregyháza, 2017.06.01., p. 333-339, ISBN 978-9637064-35-7

[11] PÁCZELT I., SZABÓ T., BAKSA A.: A végeselem-módszer alapjai, készült $a$ HEFOP 3.3.1-P.-2004-09-0102/1.0 pályázat támogatásával, 2007.

[12] Y. ZHANG, J.C. OUTEIRO, T. MABROUKI: On the Selection of Johnson-Cook Constitutive Model Parameters for Ti-6Al-4 V Using Three Types of Numerical Models of Orthogonal Cutting, 15th, CIRP Conference on Modelling of Machining Operations, Procedia CIRP, Volume 31, 2015, p. 112117. Downloaded: 2017.08.10., http://www.sciencedirect.com/science/articl e/pii/S2212827115002504

\section{NOMINATIONS}

$\begin{array}{lll}\text { A } & {[\mathrm{MPa}]} & \text { initial yield stress } \\ \text { B } & {[\mathrm{MPa}]} & \text { hardening constant }\end{array}$




\begin{tabular}{|c|c|}
\hline $\mathrm{C} \quad[-]$ & strain rate constant \\
\hline $\begin{array}{l}\mathrm{D}_{1}, \mathrm{D}_{2}, \mathrm{D}_{3}, \mathrm{D}_{4}, \mathrm{D}_{5} \\
\text { constants }\end{array}$ & {$[-]$ material } \\
\hline $\mathrm{K}_{\mathrm{CSM}}[\mathrm{mm}]$ & height of the tool nose \\
\hline $\mathrm{K}_{\mathrm{H}} \quad[\mathrm{mm}]$ & total length of the tool \\
\hline $\begin{array}{l}\mathrm{K}_{\text {SZM }}[\mathrm{mm}] \\
\text { shank }\end{array}$ & height of the tool \\
\hline $\mathrm{K}_{\mathrm{SZSZ}}[\mathrm{mm}]$ & width of the tool shank \\
\hline $\mathrm{K}_{\mathrm{TH}} \quad[\mathrm{mm}]$ & length of the tool body \\
\hline $\mathrm{K}_{\mathrm{TM}} \quad[\mathrm{mm}]$ & height of the tool body \\
\hline $\mathrm{L}_{\mathrm{SZ}} \quad[\mathrm{mm}]$ & width of insert \\
\hline $\begin{array}{l}\mathrm{m} \quad[-] \\
\text { exponent }\end{array}$ & thermal softening \\
\hline$[-]$ & hardening exponent \\
\hline$[\mathrm{K}]$ & material temperature \\
\hline $\mathrm{T}_{\mathrm{m}} \quad[\mathrm{K}]$ & melting temperature \\
\hline $\mathrm{T}_{\mathrm{r}} \quad[\mathrm{K}]$ & room temperature \\
\hline $\begin{array}{l}\alpha_{o} \quad\left[{ }^{\circ}\right] \\
\text { clearance angle }\end{array}$ & front orthogonal \\
\hline$\alpha_{o}^{\prime} \quad\left[{ }^{\circ}\right]$ & side clearance angle \\
\hline$\left.\gamma_{\mathrm{o}} \quad{ }^{\circ}\right]$ & orthogonal rake angle \\
\hline$\varepsilon_{\mathrm{p}} \quad[-]$ & effective plastic strain \\
\hline$\varepsilon^{\mathrm{f}} \quad[-]$ & strain to fracture \\
\hline$\dot{\varepsilon} \quad\left[\frac{1}{s}\right]$ & rate of the von Mises \\
\hline plastic equivalent st & \\
\hline$\dot{\varepsilon_{0}} \quad\left[\frac{1}{s}\right]$ & reference strain rate \\
\hline $\begin{array}{l}\sigma \quad[\mathrm{MPa}] \\
\text { stress }\end{array}$ & von Mises tensile flow \\
\hline $\left.\begin{array}{l}\kappa_{\mathrm{r}} \\
\text { angle }\end{array}{ }^{\circ}\right]$ & cutting-edge \\
\hline$\kappa_{\mathrm{r}}^{\prime} \quad\left[{ }^{\circ}\right]$ & side cutting-edge angle \\
\hline$\left.\lambda_{s} \quad{ }^{\circ}\right]$ & angle of guide \\
\hline
\end{tabular}

